\title{
Frizzled3 Is Required for Neurogenesis and Target Innervation during Sympathetic Nervous System Development
}

\author{
Alissa Armstrong, Yun Kyoung Ryu, Deanna Chieco, and Rejji Kuruvilla \\ Department of Biology, Johns Hopkins University, Baltimore, Maryland 21218
}

The sympathetic nervous system has served as an amenable model system to investigate molecular mechanisms underlying developmental processes in the nervous system. While much attention has been focused on neurotrophic factors controlling survival and connectivity of postmitotic sympathetic neurons, relatively little is known about signaling mechanisms regulating development of sympathetic neuroblasts. Here, we report that Frizzled3 (Fz3), a member of the Wnt receptor family, is essential for maintenance of dividing sympathetic neuroblasts. In $\mathrm{Fz}^{-1-}$ mice, sympathetic neuroblasts exhibit decreased proliferation and premature cell cycle exit. $\mathrm{Fz}^{-1-}$ sympathetic neuroblasts also undergo enhanced apoptosis, which could not be rescued by eliminating the proapoptotic factor, Bax. These deficits result in reduced generation of sympathetic neurons and pronounced decreases in the size of sympathetic chain ganglia. Furthermore, the axons of sympathetic neurons that persist in $\mathrm{Fz} 3^{-1-}$ ganglia are able to extend out of sympathetic ganglia toward distal targets, but fail to fully innervate final peripheral targets. The cell cycle exit, but not target innervation, defects in $\mathrm{Fz}^{-1-}$ mice are phenocopied in mice with conditional ablation of $\beta$-catenin, a component of canonical Wnt signaling, in sympathetic precursors. Sympathetic ganglia and innervation of target tissues appeared normal in mice lacking a core planar cell polarity (PCP) component, Vangl2. Together, our results suggest distinct roles for Fz3 during sympathetic neuron development; Fz3 acts at early developmental stages to maintain a pool of dividing sympathetic precursors, likely via activation of $\beta$-catenin, and Fz3 functions at later stages to promote innervation of final peripheral targets by postmitotic sympathetic neurons.

\section{Introduction}

The sympathetic nervous system, a branch of the autonomic nervous system, is critical for tissue homeostasis. Postganglionic sympathetic neurons innervate a variety of peripheral targets to regulate several physiological processes including blood glucose levels, cardiac output and body temperature. Development of the sympathetic nervous system is coordinated by a combination of intrinsic transcriptional determinants, and extrinsic signals derived from neighboring vasculature and peripheral targets. Sympathetic neurons are generated from sympathoadrenal precursors that originate from the dorsal neural tube and migrate ventrally to coalesce into ganglia in the vicinity of the dorsal aorta. Migration of sympathetic precursors is controlled by the receptor tyrosine kinases, ErbB2/3 (Britsch et al., 1998) and Ret (Enomoto et al., 2001), as well as the guidance receptors, neuropilin1 (Kawasaki et al., 2002) and Plexin A3/A4 (Waimey et al., 2008).

\footnotetext{
Received Aug. 13, 2010; revised Dec. 2, 2010; accepted Dec. 16, 2010.

This work was supported with funds from the National Institutes of Health (R01 MH080738) and a Whitehall Foundation award to R.K. We thank Jeremy Nathans, Michael Deans and Charles Gerfen for providing $\mathrm{Fz}_{3}{ }^{+/-}$, Vangl $2^{\mid p /+}$ and $T H$-Cre mice, respectively, and J.-F. Brunet for the Phox2b antibody. We thank Haiqing Zhao, Samer Hattar, Michael Deans, Maria Ascano, and Daniel Bodmer for comments on the manuscript and helpful discussions. D. Chieco's present address: Tufts University School of Medicine, Boston, MA 02111.

Correspondence should be addressed to Reji Kuruvilla, Department of Biology, Johns Hopkins University, Baltimore, MD 21218. E-mail: rkuruvilla@jhu.edu.

DOI:10.1523/JNEUROSCI.4243-10.2011

Copyright $\odot 2011$ the authors $\quad 0270-6474 / 11 / 312371-11 \$ 15.00 / 0$
}

Acquisition of noradrenergic features including expression of dopamine $\beta$-hydroxylase $(\mathrm{D} \beta \mathrm{H})$ and tyrosine hydroxylase $(\mathrm{TH})$ occurs early in development, and is dependent on transcriptional regulators Mash1, Phox2a/2b, Hand2 and Gata3, as well as diffusible signals such as bone morphogenetic proteins (BMPs) secreted by the dorsal aorta (Goridis and Rohrer, 2002; Howard, 2005). Upon completion of neurogenesis, postmitotic sympathetic neurons are influenced by several extrinsic cues including hepatocyte growth factor, artemin, neurotrophin-3, and nerve growth factor (NGF), to coordinate axonal outgrowth, extension along the vasculature, final target innervation and survival (Glebova and Ginty, 2005). It has been postulated that the majority of the final complement of sympathetic neurons is generated by intensive proliferation of immature noradrenergic sympathetic neuroblasts over a period lasting several days [embryonic day 12.5 (E12.5)-E17.5 in rodents] (Hendry, 1977; Rothman et al., 1978; Rubin, 1985; Fagan et al., 1996). Sympathetic neuroblasts differ from their peripheral sensory and parasympathetic neuronal counterparts and CNS precursors in that they express markers of mature neurons including catecholamine synthesizing enzymes, $\beta$-III-tubulin and neurofilament proteins and even bear neuritic processes, but still undergo massive proliferation (Rothman et al., 1978, 1980; Rohrer and Thoenen, 1987; DiCicco-Bloom et al., 1990). While several molecular players have been shown to promote proliferation of cultured sympathetic neuroblasts in vitro (DiCicco-Bloom and Black, 1988; DiCicco-Bloom et al., 1990, 2000; Pincus et al., 1990), the signals that 
control proliferation of noradrenergic sympathetic neuroblasts in vivo remains unknown.

Wnt signaling through seven-pass transmembrane Frizzled receptors has been implicated in several developmental events in the nervous system including cell fate specification, cell proliferation, neuronal survival and connectivity (Ciani and Salinas, 2005). During peripheral nervous system (PNS) development, sensory dorsal root ganglia exhibit marked reductions in size in mice lacking both Wnt1/Wnt3a (Ikeya et al., 1997) or with conditional deletion of the cytoplasmic Wnt effector, $\beta$-catenin, in premigratory neural crest cells (Hari et al., 2002). However, primordial sympathetic ganglia, which are also derived from neural crest precursors, appear normal in these mutant mice. Currently, 19 Wnt and 10 Frizzled genes have been identified in mammals. Despite the widespread expression of Wnts and Frizzleds in the nervous system and their involvement in almost every aspect of neuronal development in multiple neuronal populations, there is limited information so far about the contribution of Wnt/Frizzled signaling to sympathetic nervous system development. Recently, we defined a role for Wnt5a expressed in sympathetic neurons in mediating axon branching and innervation of final targets during late stages of sympathetic neuron development (Bodmer et al., 2009). Here, we report that Frizzled3 (Fz3) is essential for the normal generation of postganglionic sympathetic neurons. Our analysis of Fz3-deficient mice revealed fewer S-phase proliferating neuroblasts, premature cell cycle exit and enhanced apoptosis in early-stage superior cervical ganglia (SCGs), compared with wild-type littermates. $\mathrm{Fz}^{-1-}$ embryos also showed marked reductions and in some cases, complete absence of sympathetic innervation of several peripheral targets. The neurogenesis, but not innervation, defects in $\mathrm{Fz}^{-/-} \mathrm{em}-$ bryos are also observed in mice lacking $\beta$-catenin specifically in the sympathetic neuron lineage. Analysis of homozygous Looptail $(L p / L p)$ mice mutant for Vangl2 (Kibar et al., 2001; Montcouquiol et al., 2003), which encodes for a core PCP gene, did not reveal any sympathetic nervous system deficits similar to that observed in $F z 3^{-/-}$mice. These results identify a critical role for a Fz3/ $\beta$-catenin signaling pathway in neurogenesis of sympathetic neurons by maintaining a pool of dividing sympathetic precursors. Additionally, our results indicate that Fz3, but not $\beta$-catenin, regulates innervation of final peripheral targets by postmitotic sympathetic neurons.

\section{Materials and Methods}

Animals. Heterozygous $\mathrm{Fz}^{+/-}$mice were mated to obtain $\mathrm{Fz}^{-/-}$and wild-type littermates at various embryonic stages and at postnatal day 0.5 (P0.5). As reported previously, $F z 3^{-\prime-}$ mice die within a few hours of birth (Wang et al., 2002). To generate conditional mutants of $\beta$-catenin, floxed $\beta$-catenin $\left(\beta\right.$-Ctn $\left.{ }^{f l f l}\right)$ mice (Jackson Laboratory) were crossed to $\mathrm{TH}$-Cre mice. Intercrosses between $\mathrm{Fz}^{+/-} ; \mathrm{Bax}^{+/-}$double heterozygotes were set up to obtain $\mathrm{Fz}^{-/-} ; \mathrm{Bax}^{-1-}$ mice and relevant controls. $\mathrm{Bax}^{+/-}$mice were obtained from Jackson Laboratory. All procedures relating to animal care and treatment conformed to institutional and National Institutes of Health guidelines.

In situ hybridization. In situ hybridization was performed using digoxigenin labeled probes spanning the junction of exons 6 and 7 of Frizzled3. E14.5, E16.5, and P0.5 embryos were fresh frozen in OCT (Tissue-Tek) and serially sectioned $(16 \mu \mathrm{m})$ using a cryostat. Sections were postfixed in $4 \%$ paraformaldehyde (PFA), washed in PBS, acetylated with $0.25 \%$ acetic anhydride in $0.1 \mathrm{M}$ triethanolamine with $0.9 \%$ $\mathrm{NaCl}$. After hybridization with the labeled RNA probe $(2 \mu \mathrm{g} / \mathrm{ml})$ at $68^{\circ} \mathrm{C}$ overnight, sections were washed with $0.2 \times \mathrm{SSC}$ buffer at $65^{\circ} \mathrm{C}$, blocked with TBS containing $1 \%$ normal goat serum and then incubated with alkaline phosphatase-labeled anti-DIG antibody (1:5000; Roche) overnight at $4^{\circ} \mathrm{C}$. The alkaline phosphatase reaction was visualized with ni- troblue tetrazolium/5-bromo-4-chloro-indolyl phosphate, rinsed in PBS, fixed in 4\% PFA and mounted in AquaMount (EMD Chemicals).

Immunohistochemical analysis. Embryos at various developmental ages were fixed in $4 \%$ PFA at $4^{\circ} \mathrm{C}$ for 3-4 h, cryoprotected in $30 \%$ sucrose in PBS, frozen in OCT and serially sectioned $(10 \mu \mathrm{m})$. For immunofluorescence, sections were washed in PBS, permeabilized in PBS containing $1 \%$ Triton $\mathrm{X}-100$, and blocked using $5 \%$ goat serum in PBS $+0.5 \%$ Triton X-100. For diaminobenzidine (DAB) immunohistochemistry, endogenous peroxidase activity was quenched in $1 \% \mathrm{H}_{2} \mathrm{O}_{2}$ before blocking. Sections were incubated in the following primary antibodies overnight: mouse anti-TH (1:200, Sigma-Aldrich), rabbit anti-TH (1:200, Millipore), rat anti-Ki67 (1:100, Dako), rabbit anti-Phox2b (1:200, a kind gift from Jean-Francois Brunet, Institut de Biologie de l'Ecole Normale Supérieure, Paris, France) and rabbit anti-cleaved caspase3 (1:200, Cell Signaling Technology). Nuclear antigens, Phox2b and Ki67, were subjected to antigen retrieval by boiling sections for $15 \mathrm{~min}$ in $1 \mathrm{M}$ sodium citrate in $0.5 \%$ Tween 20. Following PBS washes, sections were incubated in the appropriate secondary antibodies, diluted 1:200 (anti-mouse Alexa Fluor $488 \operatorname{IgG} \gamma 1$, anti-rabbit Alexa Fluor 488 or Alexa Fluor 546 or anti-rat Alexa Fluor 594 (Invitrogen) for immunofluorescence and antirabbit-HRP (GE Healthcare) for DAB immunohistochemistry. Sections were then washed in PBS and mounted in VectaShield (Vector Laboratories) containing $100 \mu \mathrm{g} / \mathrm{ml} \mathrm{4'}$, $6^{\prime}$-diamidino-2-phenylindole dihydrochloride. For colorimetric readout, following secondary antibody incubation, immunoreactivity was detected with diaminobenzidine (Sigma-Aldrich), sections were dehydrated in a graded series of ethanol (50\%, 70\% and 100\%) and mounted in Permount (Fisher Scientific). Whole-mount $\mathrm{TH}$ immunostaining to visualize sympathetic chains and axons was performed on E12.5, E16.5, and P0.5 mouse embryos as described previously (Bodmer et al., 2009).

Neuronal cell counts. E13.5, E14.5, E16.5, and P0.5 mice for neuronal counts were prepared as described previously by Bodmer et al. (2009). Briefly, mouse torsos were fixed in PBS containing 4\% PFA, and then cryoprotected overnight in $30 \%$ sucrose-PBS. Superior cervical ganglion (SCG) sections $(10 \mu \mathrm{m})$ were stained with a solution containing $0.5 \%$ cresyl violet (Nissl). Cells with characteristic neuronal morphology and visible nucleoli were counted in every fifth Nissl stained section. In some cases, sections were also stained for $\mathrm{TH}$, and immunopositive cells were counted in every fifth section.

Analyses of proliferation. E13.5 pregnant $\mathrm{Fz}^{+/-}$dams were injected intraperitoneally with Click-IT EdU (125 $\mu \mathrm{g} / \mathrm{ml}$ in PBS, Invitrogen), embryos harvested $2 \mathrm{~h}$ later and prepared for immunofluorescence. EdU is a thymidine analog, which like the commonly used bromodeoxyuridine, is incorporated into dividing cells during S-phase but can be easily detected without heat or acid treatment and is thus more compatible for use in fluorescence immunohistochemical analyses (Cappella et al., 2008). Tissue sections $(10 \mu \mathrm{m})$ were immunolabeled for TH to visualize the SCG, and the Click-IT EdU reaction was performed according to the manufacturer's protocol to visualize the EdU label. The total number of cells that incorporated EdU in each section were counted and summed for an entire SCG. To assess cell cycle exit, $\mathrm{Fz}^{+/-}$dams at gestational age E12.5 were injected with Click-IT EdU and harvested $24 \mathrm{~h}$ later at E13.5. Following antigen retrieval, sections were immunolabeled with rat anti-Ki67. Cell cycle exit was calculated by determining the percentage of cells positive for EdU but negative for Ki67 among the total number of EdU-labeled cells. To assess cell death of dividing precursors, $\mathrm{Fz}^{+/-}$dams at gestational age E13.5 were injected with Click-IT EdU and embryos were harvested $2 \mathrm{~h}$ later. Visualization of the Click-IT EdU was performed following detection of cell death using terminal deoxynucleotidyl transferase-mediated biotinylated UTP nick end labeling (TUNEL) staining (Roche) according to the manufacturer's protocol. Apoptosis of dividing precursors was calculated by determining the percentage of cells double positive for TUNEL and EdU among the total number of TUNEL-positive cells.

Neuronal cultures and quantification of neurite length and axon branching. Quantification of neurite outgrowth in SCG explants, as well as neurite length and axon branching in dissociated neuronal cultures was performed as previously described (Bodmer et al., 2009). For explants, SCGs dissected from E18.5 wild-type and $F z 3^{-1-}$ embryos were cultured in collagen gel in media containing NGF $(25 \mathrm{ng} / \mathrm{ml})$ for $48 \mathrm{~h}$ and then 

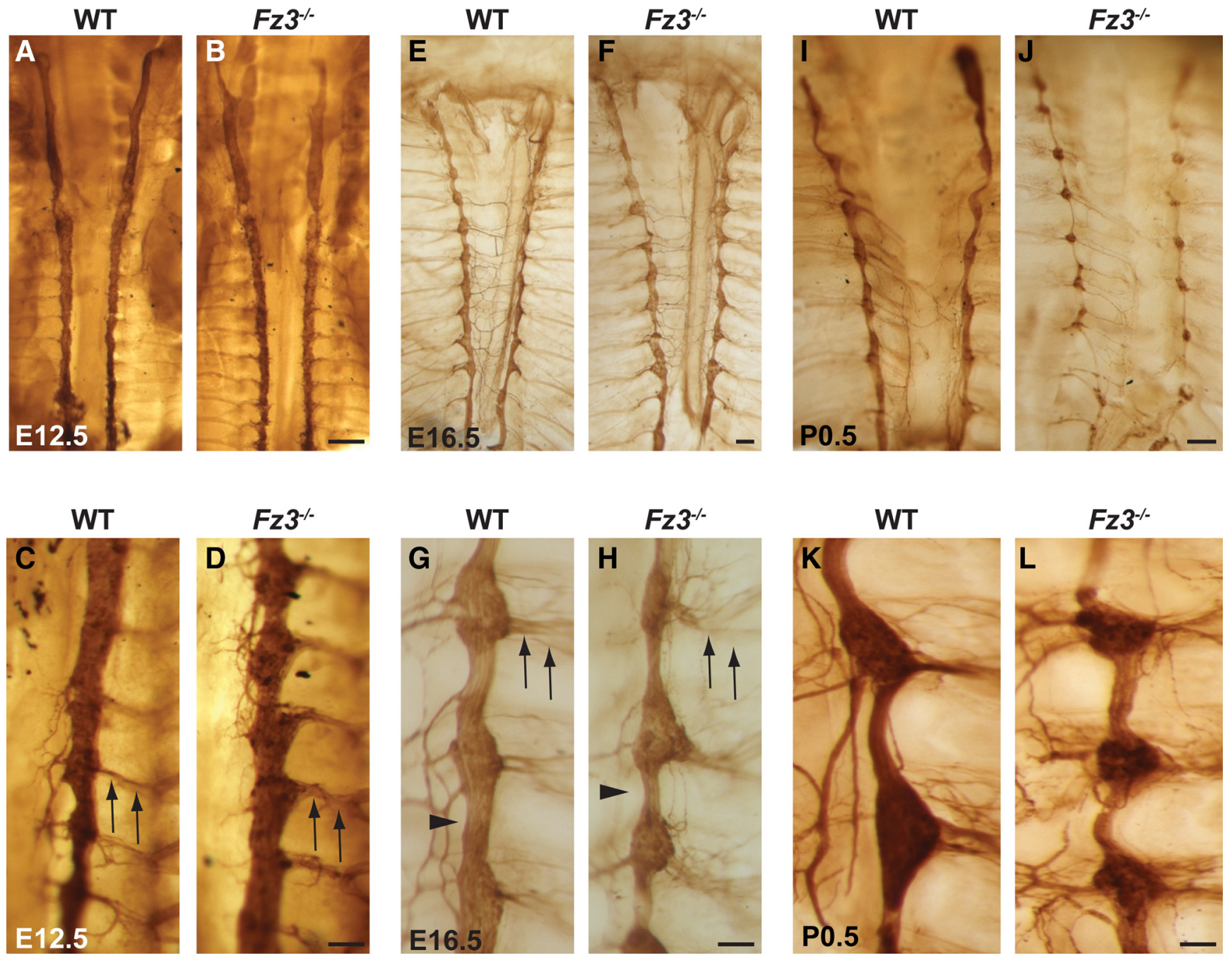

Figure 1. Aberrant development of sympathetic chain ganglia in $F z 3^{-/-}$mice. $\boldsymbol{A}-\boldsymbol{L}$, Whole-mount tyrosine hydroxylase staining of E12.5 (A-D), E16.5 (E-H), and P0.5 (I-L) wild-type and $\mathrm{Fz}_{3}{ }^{-\prime-}$ embryos. Normal segmented organization of the sympathetic chains and TH expression is observed in $\mathrm{Fz}_{2}{ }^{-/-}$embryos at all stages. However, $\mathrm{Fz}_{3}{ }^{-/-}$sympathetic chain shows obvious hypoplasia by P0.5 (compare $\boldsymbol{I}$ and $\boldsymbol{J}$ ). Closer examination of thoracic sympathetic chain ganglia show that ganglia size in $F z 3^{-/-}$mice is slightly reduced at E16.5 $(\mathbf{G}, \boldsymbol{H})$ and markedly atrophic at P0.5 $(\boldsymbol{K}, \boldsymbol{L})$. Projections between ganglia $\left(\boldsymbol{G}, \boldsymbol{H}\right.$, arrowheads) and emanating from ganglia $\left(\mathbf{G}, \boldsymbol{H}\right.$, arrows) are thinner in $\mathrm{Fz}^{-}{ }^{-/-}$embryos. The lower- and higher-magnification images are taken from different animals for each developmental stage. Number of animals examined for each time point: $n=8$ for each genotype (12.5), $n=7$ (E16.5 and P0.5). Scale bars: $A, B, E, F, I, J, 250 \mu \mathrm{m} ; C, D$, $G, H, K, L, 125 \mu \mathrm{m}$.

immunostained with $\beta$ III-tubulin (Sigma-Aldrich). Neurite outgrowth in SCG explants was quantified by measuring the area covered by the axons of each explant relative to the area occupied by the cell bodies. Low-density cultures were established from E18.5 wild-type and $\mathrm{Fz}^{-{ }^{--}}$ embryos and cultured on polylysine-coated coverslips for $24 \mathrm{~h}$. Neurons were labeled with $\beta$-III tubulin and/or phalloidin to visualize neuronal morphologies. Neurons were imaged using a Zeiss Axiovision microscope with a AxioCam HRC digital camera and analyzed with Axiovision software. Length (micrometers) of the longest neurite as well as the total number of branch points was quantified for each neuron.

Statistical analyses. Statistical comparisons were determined by the Student's $t$ test for pair comparisons and by one-way ANOVA for multiple comparisons. Post hoc analyses were done using Tukey-Kramer's test. Values and error bars indicate mean \pm SEM.

\section{Results}

Sympathetic chain ganglia exhibit hypoplasia in $\mathrm{Fz}^{-/-}$mice To determine the role of Fz3 in sympathetic nervous system development, we examined the paravertebral sympathetic chains in $\mathrm{Fz}^{-1-}$ mouse embryos using whole-mount tyrosine hydroxylase immunostaining. At E12.5, a stage when the sympathetic chains are still uniform columns of actively proliferating precursors, no morphological differences were apparent between $\mathrm{Fz}^{-/-}$and wild-type embryos (Fig. 1A-D). Neuronal precursors in mutant embryos start extending axons, similar to that observed in wildtype embryos (Fig. 1C,D, arrows). The normal formation of the sympathetic chains and $\mathrm{TH}$ expression in Fz3 mutant embryos suggested that dorsoventral migration of neural crest-derived sympathetic precursors and expression of sympathetic lineage markers were unaffected by the absence of Fz3. Normal expression of noradrenergic markers in $\mathrm{Fz}^{-/-}$sympathetic ganglia was also confirmed by immunostaining for Phox2b (supplemental Fig. 1, available at www.jneurosci.org as supplemental material), a homeodomain transcription factor necessary for the induction and maintenance of lineage-specific markers including TH and $\mathrm{D} \beta \mathrm{H}$ in sympathetic neurons (Pattyn et al., 1999). At E16.5, when sympathetic axons begin innervating peripheral targets, the chain ganglia appear as discrete, segmented condensations in both wild-type and mutant embryos (Fig. $1 E-H$ ). However, a closer inspection revealed that in $\mathrm{Fz}^{-/-}$embryos, sympathetic chain 
ganglia were slightly diminished in size; axonal bundles connecting the ganglia appeared thinner (Fig. 1G,H, arrowheads) while some level of disorganization was seen in projections emanating from the ganglia toward the periphery (Fig. $1 G, H$, arrows). At P0.5, a stage when many sympathetic axons have reached or are actively innervating target tissues, $\mathrm{Fz}^{-/-}$sympathetic chains were markedly atrophic with smaller ganglia throughout the rostrocaudal extent of the chain and sparser axonal projections (Fig. $1 I-L$ ).

To better characterize the defects in sympathetic chain ganglia in $\mathrm{Fz}^{-/-}$mice, we focused our analyses on the superior cervical ganglia (SCG), the most rostral ganglia in the sympathetic chain. We used in situ hybridization to assess $F z 3$ expression in the developing SCG. Fz3 expression was observed in the SCG at all the developmental stages examined (E14.5, Fig. 2A, B; E16.5, Fig. 2C,D; and P0.5, Fig. $2 E, F)$. Prominent expression of $F z 3$ at E14.5, a stage when the SCG is comprised primarily of proliferating sympathetic neuroblasts (Fagan et al., 1996; Francis et al., 1999) suggests that Fz3 is expressed in cells of neuronal origin. We performed $\mathrm{TH}$ immunohistochemistry to visualize the SCG and Nissl staining to quantify SCG cell numbers in wild-type (Fig. $2 G, I, K, M$ ) and $\mathrm{Fz}^{-/-}$embryos (Fig. $2 H, J, L, M)$ at various developmental stages. We initiated our analysis at E13.5 when sympathetic ganglia have just coalesced. The wild-type SCG increases in size from E13.5 to E16.5, a time period of robust neurogenesis in the SCG (Fagan et al., 1996; Francis et al., 1999). There is a concomitant increase in SCG cell number from E13.5 (13,714.5 \pm 551.4) to E16.5 $(20,823.52 \pm 1075.9)$ (Fig. $2 M)$. However, in $\mathrm{Fz}^{-/-}$mice, significant reductions in SCG cell numbers compared with wild-type embryos were observed at E13.5 (29.8\% decrease) and E14.5 (39.15\% decrease) (Fig. $2 M$ ). By E16.5, when neurogenesis is being completed in the murine SCG (Francis et al., 1999), the Fz3 ${ }^{-/-}$ SCG was dramatically reduced in size (Fig. $2 J)$, possessing $68.6 \%$ fewer cells than in wild-type embryos (Fig. $2 \mathrm{M}$ ). The cell loss observed in $\mathrm{Fz}^{-1-}$ SCGs was maximal at E16.5, and no further depletions in cell number were observed between E16.5 and P0.5 (Fig. 2M), when SCG axons are actively innervating target regions and depending on target-derived neurotrophic support (Rubin, 1985; Fagan et al., 1996). A similar decrease in cell numbers was also evident in the stellate ganglion, a second large ganglion immediately caudal to
E14.5
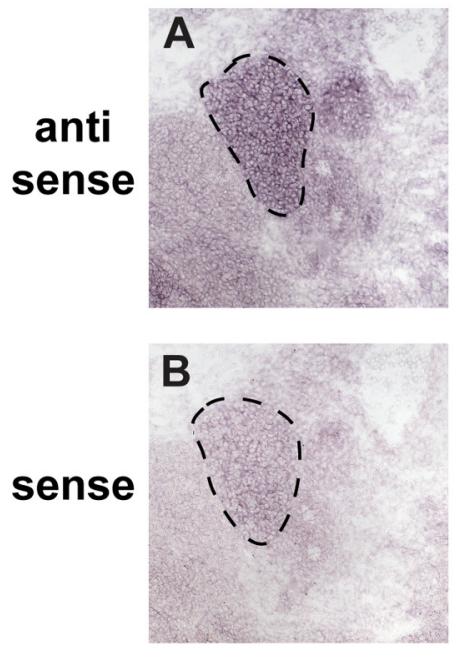

E14.5
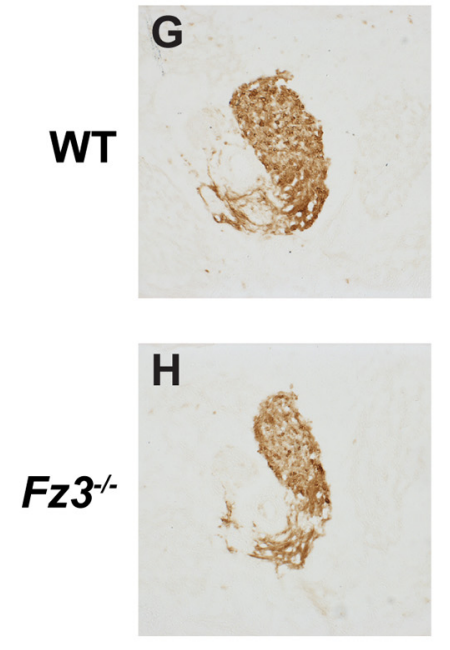

M
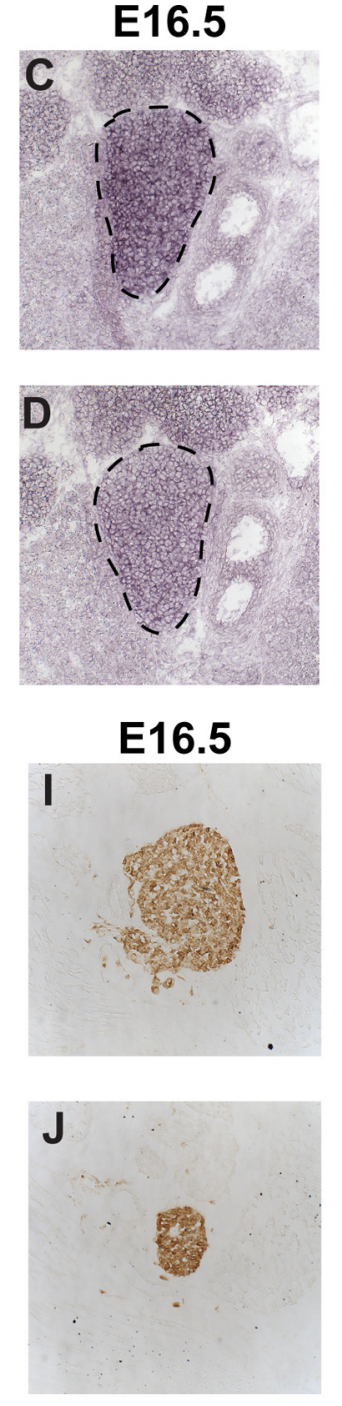

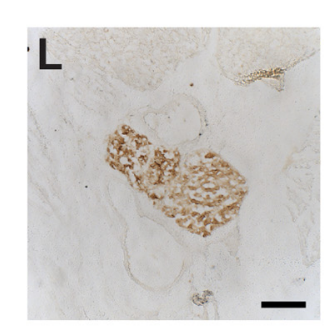

P0.5
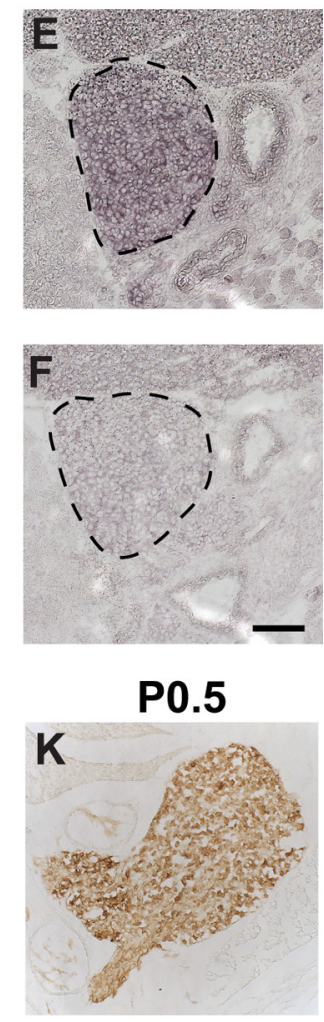

WT Fz3

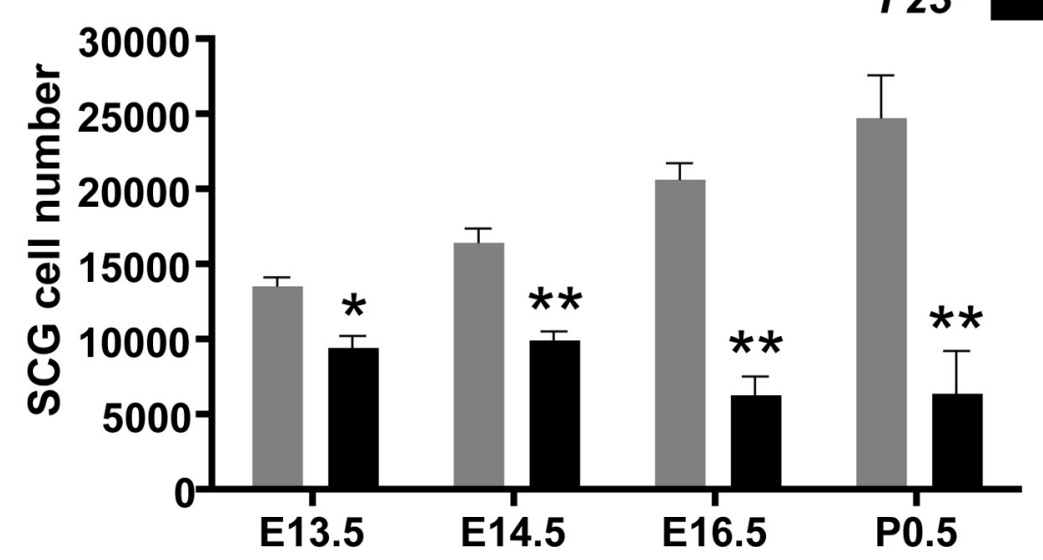

Figure 2. Superior cervical ganglia (SCG) show reductions in ganglia size and cell number in $\mathrm{Fz}^{-1-}$ embryos. $\boldsymbol{A}, \boldsymbol{C}, \boldsymbol{E}$, In situ hybridization shows expression of $F z 3$ in the developing SCG at E14.5 (A), E16.5 (C), and P0.5 (E). B, D, F, Sense controls for each time point are shown. Dashed lines outline the SCG. $\mathbf{G}-\boldsymbol{L}$, TH immunohistochemistry of comparable sections through wild-type $(\mathbf{G}, \boldsymbol{I}, \boldsymbol{K})$ and $F z 3^{-/-}(\boldsymbol{H}$, $J, L)$ SCGs atE14.5, E16.5, and P0.5. In Fz3 ${ }^{-/-}$mice, there is a modest reduction in SCG size atE14.5 compared with the wild-type SCG, while a severe reduction in ganglion size is observed at E16.5 that persists until birth (P0.5). Scale bar, $100 \mu \mathrm{m}$. M, Quantification shows marked reductions in $\mathrm{SCG}$ cell numbers in $\mathrm{Fz}^{-1-}$ embryos compared with wild-type ganglia, at all developmental stages examined. Values are the mean \pm SEM ( $n=6$ embryos for each genotype at E13.5, $n=10$ for wild-type and $n=7$ for $F z 3^{-1-}$ atE14.5, $n=6$ for wild-type and $n=5$ for $F z 3^{-1-}$ at E16.5 and $n=4$ embryos for each genotype at P0.5). ${ }^{*} p<0.05,{ }^{* *} p<0.001$. 


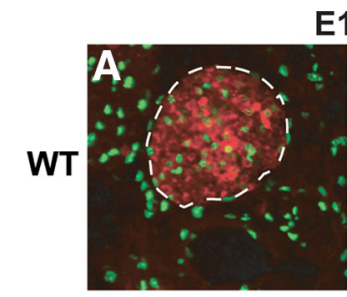

E13.5

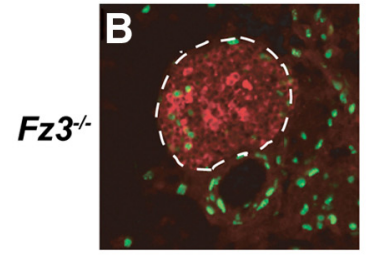

$\mathrm{TH}$

EdU
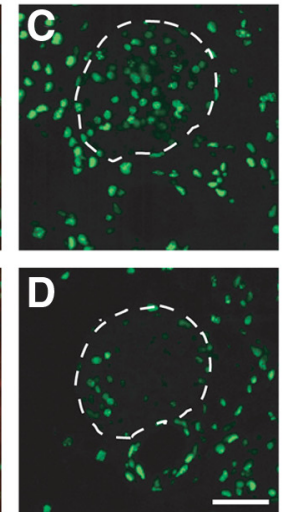

EdU

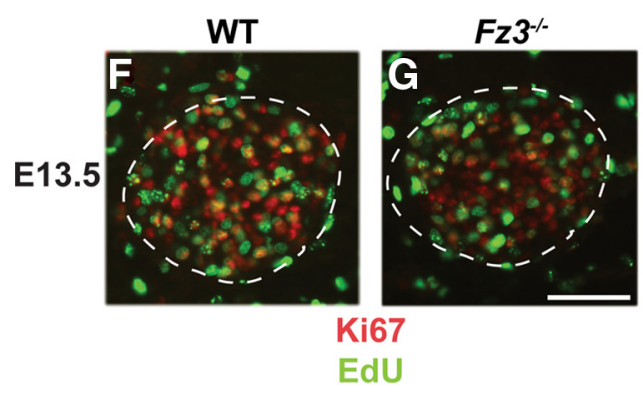

\section{H}

E
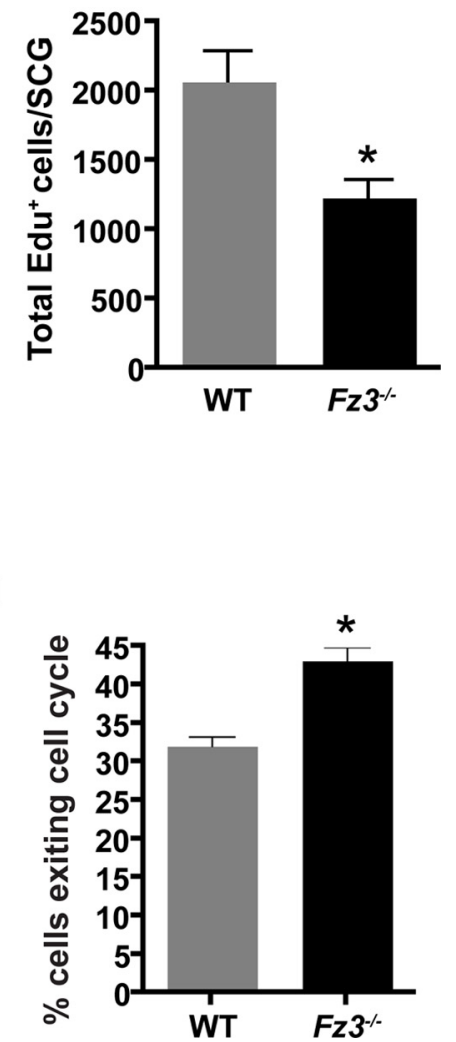

Figure 3. $\quad F z 3$ is required for proliferation and cell cycle progression in sympathetic ganglia. $\boldsymbol{A}-\boldsymbol{E}$, After a $2 \mathrm{~h}$ pulse of $\mathrm{EdU}$ at E13.5, fewer S-phase proliferating sympathetic neuroblasts labeled with TH are seen in $\mathrm{Fz}_{3}{ }^{-1-} \mathrm{SCG}(\boldsymbol{B}, \boldsymbol{D})$ compared with wild-type $(A, C)$. , Quantification of the total number of EdU-positive, proliferating cells per SCG. Values are the mean \pm SEM $(n=$ 4 embryos analyzed for each genotype). ${ }^{*} p=0.016$. Scale bar, $100 \mu \mathrm{m}$. $\boldsymbol{F}-\boldsymbol{H}$, Analysis of cell cycle exit within a $24 \mathrm{~h}$ period in $\mathrm{FZ}{ }^{-1-}$ and wild-type embryos. After a $24 \mathrm{~h}$ pulse of EdU at E12.5, fewer cycling progenitors positive for both EdU (green) and Ki67 (red) are seen in $\mathrm{Fz}_{2}{ }^{-1-} \mathrm{SCG}(\boldsymbol{G})$, compared with wild-type $(\boldsymbol{F})$. Scale bar, $100 \mu \mathrm{m}$. $\boldsymbol{H}$, Quantification of cell cycle exit, calculated as the percentage of cells that are EdU ${ }^{+}, \mathrm{Ki}_{67}{ }^{-}$of the total number of EdU-labeled cells, shows that significantly more cells have exited the cell cycle in $\mathrm{FZ}_{2}{ }^{-/-} \mathrm{SCG}$ than in wild type. Values are the mean $\pm \mathrm{SEM}$ ( $n=3$ embryos for each genotype). ${ }^{*} p=$ 0.0068 .

the SCG in the sympathetic chain in $\mathrm{Fz}^{-/-}$embryos (supplemental Fig. 2, available at www.jneurosci.org as supplemental material). Together, these results reveal that $\mathrm{Fz} 3$ is dispensable for early events in sympathetic chain formation including migration and noradranergic specification, but, is essential for regulating a developmental increase in sympathetic ganglia size.

Fz3 is necessary for proliferation of sympathetic neuroblasts Since the reduction in cell numbers in $\mathrm{Fz}^{-{ }^{--}}$SCG is evident during a period of neurogenesis, we assessed cellular proliferation in wild-type and $\mathrm{Fz}^{-/-}$SCGs using 5-ethynyl-2'-deoxyuridine (EdU) incorporation. The SCG was identified by colabeling tissue sections with an antibody against TH (Fig. $3 A, B$ ). After a $2 \mathrm{~h}$ EdU pulse, we observed a 1.7-fold reduction in the number of proliferating sympathetic neuroblasts in the E13.5 $\mathrm{Fz}^{-/-}$SCG compared with wild-type controls (1234 \pm 128 in $\mathrm{Fz}^{-1-}$ versus $2074 \pm 217$ in wild-type) (Fig. 3C-E). To determine the cause of reduced proliferating cells in the $\mathrm{Fz}^{-1-}$ SCG, we pulse-labeled sympathetic neuroblasts with EdU at E12.5 for $24 \mathrm{~h}$, and then costained the tissue with Ki67 (Fig. 3F, G). Ki67 labels cells in all phases of the cell cycle except $\mathrm{G}_{0}$. Thus, $\mathrm{EdU}^{+} ; \mathrm{Ki} 67^{-}$cells represent those that have exited the cell cycle during the $24 \mathrm{~h}$ time interval. Our analysis revealed that significantly more sympa- thetic neuroblasts exited the cell cycle over the $24 \mathrm{~h}$ interval in the $F z 3^{-/-}$SCG (Fig. $3 H$ ). In the wild-type SCG, $32 \%$ of EdUpositive cells exited the cell cycle compared with $43 \%$ in $\mathrm{Fz}^{-/-}$SCG. Together, these results suggest that, during sympathetic nervous system development, Fz3 is necessary to maintain sympathetic neuroblasts in the cell cycle.

\section{$\mathrm{Fz}^{-/-}$sympathetic neuroblasts} undergo enhanced apoptosis

Given the dramatic reduction in SCG size in $\mathrm{Fz}^{-1-}$ embryos, we considered whether, in addition to decreased neurogenesis, cell death could also contribute to the significant loss in sympathetic neuron numbers. Thus, we used activated caspase- 3 immunostaining to assess apoptotic cell death in wild-type and $\mathrm{Fz}^{-1-}$ embryos (Fig. 4A-D). The number of caspase3-immunoreactive cells per wild-type SCG averaged $38 \pm 5$ and $49 \pm 3$ at E13.5 and E14.5, respectively (Fig. $4 E$ ). These results point to some degree of naturally occurring cell death in the nascent SCG before target innervation. However, the $\mathrm{Fz}^{-/-}$embryos showed an increase in apoptotic profiles in the SCG with $65 \pm 10$ and $83 \pm 9$ caspase3-positive cells at E13.5 and E14.5, respectively (Fig. 4E). As noted previously, the majority of cells in the SCG at E13.5-E14.5 are proliferating neuroblasts, which we independently confirmed with Ki67 and TH immunostaining (data not shown). These results suggest that enhanced apoptosis in addition to a reduction in the precursor pool as a result of premature cell cycle exit, accounts for the overall decrease in sympathetic ganglia size and cell number in $\mathrm{Fz}^{-/-}$embryos. We also analyzed apoptosis in wild-type and the $F z 3^{-1-}$ SCGs at E16.5, an intermediate period overlapping the end phase of neurogenesis and the onset of target innervation, and at $\mathrm{P} 0.5$, when sympathetic axons are actively competing for limiting amounts of target-derived neurotrophic factors. At E16.5, we observed a twofold increase in apoptotic profiles in the $\mathrm{Fz}^{-1-}$ SCG, compared with wild-type controls (caspase3-positive cells: $397 \pm 36.9$ in $\mathrm{Fz}^{-/-}$SCGs versus $191 \pm 8.3$ in wild-type SCGs) (Fig. 4E). However, at P0.5, we found no significant differences in levels of apoptosis between $\mathrm{Fz}^{-/-}$and wild-type mice (caspase3-positive cells: $202.3 \pm 92.23$ in $\mathrm{Fz}^{-{ }^{-/}}$SCGs versus $430 \pm 49.56$ in wild-type SCGs) (Fig. $4 E$ ). These results suggest that significant cell loss in $\mathrm{Fz}^{-/-}$sympathetic ganglia occurs before periods of neurotrophin dependence in vivo.

To better define the identity of the dying cells in $\mathrm{Fz}^{-/-}$sympathetic ganglia, we made use of mice lacking the proapoptotic factor, Bax. Bax is a proapoptotic member of the Bcl-2 family of proteins, and its genetic ablation results in excess cell numbers in various developing tissues including the nervous system (Deckwerth et al., 1996; White et al., 1998; Patel et al., 2000; Lindsten et al., 2003; Lindsten and Thompson, 2006). In vivo studies have shown that postmitotic sympathetic neurons die in the absence of the target-derived survival factor, NGF, and this cell death can be completely rescued by the concurrent elimination of Bax 
(Middleton and Davies, 2001; Glebova and Ginty, 2004). We reasoned that if the cells dying in $\mathrm{Fz}^{-/-}$SCGs are mature, postmitotic neurons that depend on targetderived trophic support, then enhanced apoptosis observed in $\mathrm{Fz}^{-/-}$ganglia should be prevented by genetic ablation of Bax. We found a similar depletion of SCG cell numbers in $\mathrm{Fz}^{-/-} ; \mathrm{Bax}^{-/-}$double knock-out embryos as in $\mathrm{Fz}^{-1-}$ embryos (Fig. 4G,IJ). In contrast to the P0.5 SCG, in which removal of Bax alone increases neuronal number by twofold (Middleton and Davies, 2001; Glebova and Ginty, 2004), the E16.5 SCG shows no increase in size or cell number in $\mathrm{Bax}^{-/-}$mice (Fig. $4 F, H, J$ ). This indicates that naturally occurring cell death of sympathetic neuroblasts occurs via a mechanism independent of the classical Baxmediated apoptotic pathway used by postmitotic sympathetic neurons that compete for target-derived NGF (Middleton and Davies, 2001; Glebova and Ginty, 2004). The timing of cell death during a period of robust neurogenesis in the SCG, and the Bax-independent mechanism of cell death provides strong evidence that $\mathrm{Fz} 3$ deficiency results in depletion of cycling sympathetic neuroblasts or the cells that have prematurely exited the cell cycle, rather than mature postmitotic sympathetic neurons.

To distinguish whether cycling sympathetic neuroblasts or cells that have inappropriately exited the cell cycle undergo enhanced cell death in $\mathrm{Fz}^{-1-}$ sympathetic ganglia, we assessed the percentage of stilldividing sympathetic neuroblasts that are undergoing apoptosis. E13.5 $\mathrm{Fz}^{-/-}$and wild-type embryos were pulse-labeled with EdU for $2 \mathrm{~h}$ to identify S-phase neuroblasts, and the tissue costained with TUNEL to identify dying cells. Although the percentage of TUNEL-positive cells that are also EdU-positive were found to be higher in Fz3 mutant than wild-type SCGs, $30.43 \pm 4.9 \%$ and $21.1 \pm 4.6 \%$, respectively, these numbers were not statistically different $(p=0.195$, Student's $t$ test, $n=6$ embryos for wild-type and $\mathrm{Fz}^{-/-}$embryos, supplemental Fig. 3, available at www.jneurosci.org as supplemental material). This suggests that death of cycling sympathetic neuroblasts does not significantly contribute to the reduction in SCG cell number observed in the absence of $F z 3$. Together, with the evidence presented above, we infer that cell loss in $F z 3^{-/-}$SCGs likely results from apoptosis of cells that have prematurely exited the cell cycle, but have yet to rely on survival cues coming from final targets.

\section{Sympathetic innervation of peripheral targets is reduced or absent in $\mathrm{Fz}^{-1-}$ mice}

Previous analyses of $\mathrm{Fz}^{-/-}$mice revealed profound deficits in axon growth in the developing CNS with major losses in thalamocortical, corticothalamic and nigrostriatal tracts (Wang et al., 2002). Additionally, in the absence of $F z 3$, commissural axons crossing the midline also show targeting errors in their anterior trajectory toward the brain (Lyuksyutova et al., 2003).
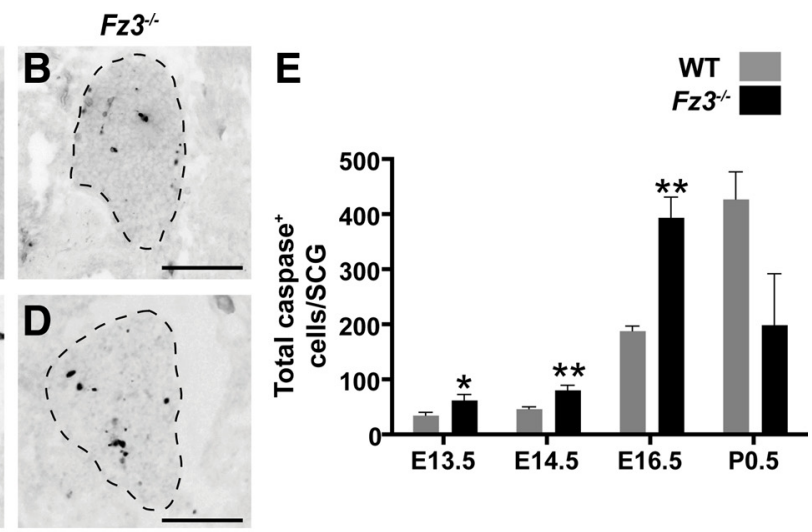

Figure 4. $\quad \mathrm{Fz}^{-/-}$sympathetic neuroblasts exhibit enhanced apoptosis, which is independent of Bax. A-D, Cleaved caspase-3 immunofluorescence shows enhanced apoptosis in E13.5 (B) and E14.5 (D) $\mathrm{Fz}_{2}{ }^{-/-}$SCG compared with wild-type ganglia (E13.5, A and E14.5, C). Dashed lines outline the SCG. Scale bar, $100 \mu \mathrm{m}$. E, Quantification shows some level of cell death occurring in the 政 $\mathrm{Fz}^{-/-}$SCGs show enhanced apoptosis compared with wild-type ganglia at E13.5, E14.5, and E16.5, but not at P0.5. Values are the SEM ( $n=13$ embryos analyzed for wild-type and $n=14$ for $F z 3^{-}$at E13.5; $n=6$ embryos for wild-type and $n=8$ $\mathrm{Fz}{ }^{-/-}$at P0.5). ${ }^{*} p<0.05$; $^{* *} p<0.01$. F-J, Reduction in SCG size and cell numbers in E16.5 Fz3 ${ }^{-/-}$mice are not rescued by the concomitant deletion of the proapoptotic molecule, Bax. TH immunostaining shows that the SCG is dramatically reduced in size in $\mathrm{FZ}{ }^{-/-} ; \mathrm{Bax}^{+/+}(\boldsymbol{G})$ and $\mathrm{Fz}_{3}{ }^{-/-} ; \mathrm{Bax}^{-/-}$double mutant $(\boldsymbol{I})$ embryos compared with that in wild-type $(\boldsymbol{F})$ or $\mathrm{Fz}^{+/+} ; \mathrm{Bax}^{-/-}$ mice $(\boldsymbol{H})$. Scale bar, $100 \mu \mathrm{m}$. J, Quantification of cell number confirmed that the reductions in $\mathrm{Fz}^{-1-}$ SCG number are not embryos compared with $\mathrm{Fz}_{2}{ }^{+/+} ; \mathrm{Bax}^{+/+}(\boldsymbol{F})$ littermate controls. Values are the mean \pm SEM $\left(n=6\right.$ embryos for $\mathrm{F}_{2} 3^{+/+}$; $\mathrm{Bax}^{+/+}, \mathrm{Fz}^{+/+} ; \mathrm{Bax}^{-1-}$ and $\mathrm{Fz}^{-/-} ; \mathrm{Bax}^{-/-}$and $n=4$ for $\left.\mathrm{Fz}^{-1-} ; \mathrm{Bax}^{+/+}\right) .{ }^{*} \mathrm{p}<0.05{ }^{* *} \mathrm{p}<0.01$.

To determine whether the postmitotic sympathetic neurons that persist in $\mathrm{Fz}^{-1-}$ embryos were capable of extending axons and reaching their peripheral targets, we used TH immunohistochemical analyses on tissue sections and whole embryos. At E14.5, TH-positive sympathetic axons extended from the SCG and projected along the neighboring carotid artery in both wildtype and $\mathrm{Fz}^{-1-}$ mice (Fig. 5A,B, arrows). Bundles of THpositive sympathetic fibers were seen coursing adjacent to the cochlea on trajectory toward more distal targets in $\mathrm{Fz}^{-/-}$mice (Fig. 5D), similar to that in wild-type embryos (Fig. 5C). However, at E16.5, several peripheral targets in $\mathrm{Fz}^{-/-}$mice showed a complete loss or severe reductions in sympathetic innervation. Sympathetic innervation is markedly reduced in salivary glands (Fig. $5 \mathrm{~F}$ ) or completely absent in the heart (Fig. $5 \mathrm{H}$ ) of $\mathrm{Fz}^{-/-}$ mice, compared with that in the wild-type tissues (Fig. $5 E, G$ ). The salivary glands receive innervation primarily from SCG sympathetic fibers, while innervation of the heart comes from the stellate ganglia, with some contribution from the SCG and thoracic paravertebral ganglia. In $\mathrm{Fz}^{-/-}$embryos, we also noted 

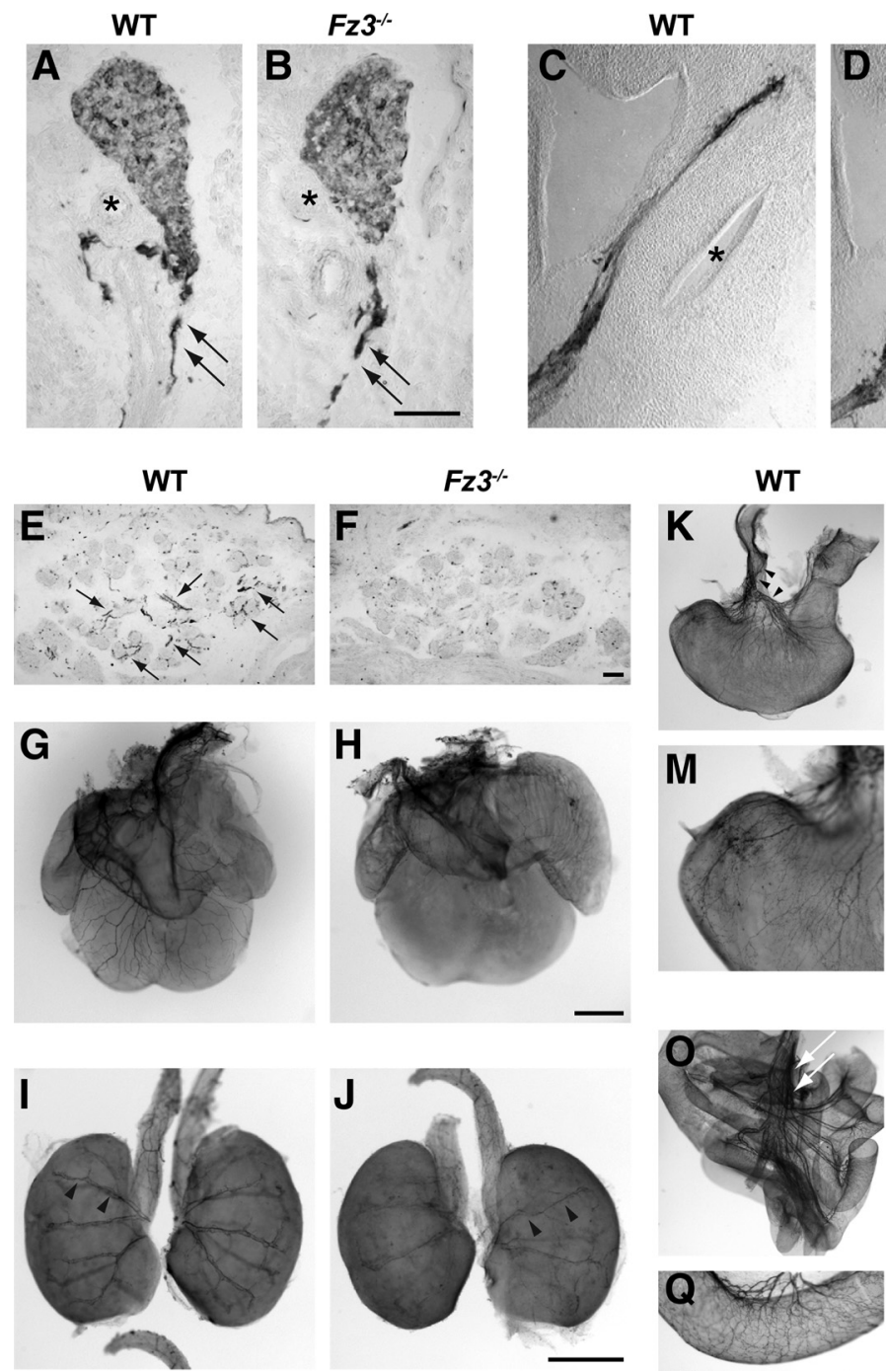

Figure 5. Decreased innervation of sympathetic target tissues in $\mathrm{Fz}^{-/-}$embryos. A-D, TH immunohistochemistry shows sympathetic axons projecting along the carotid artery $(\boldsymbol{A}, \boldsymbol{B}$, asterisks) and cochlea $(\boldsymbol{C}, \boldsymbol{D}$, asterisks) in E14.5 wild-type $(\boldsymbol{A}, \boldsymbol{C})$ and $\mathrm{Fz}^{-/-}(\boldsymbol{B}, \boldsymbol{D})$ embryos. Scale bars, $100 \mu \mathrm{m} . \boldsymbol{E}, \boldsymbol{F}$, TH immunostaining of tissue sections show the presence of sympathetic fibers in E16.5 wild-type ( $\boldsymbol{E}$, arrows) but not in $F z^{-/-}$salivary glands $(\boldsymbol{F})$. Scale bar, $100 \mu \mathrm{m}$. $\mathbf{G}-\boldsymbol{R}$, Whole-mount TH immunostaining of several peripheral targets shows incomplete to no sympathetic innervation in $\mathrm{E} 16.5 \mathrm{Fz}^{-/-}$embryos. TH-positive sympathetic fibers were completely absent in the $\mathrm{Fz}_{2} 3^{-/-}$heart $(\boldsymbol{H})$ compared with wild type $(\boldsymbol{G})$. The kidneys $(\boldsymbol{J})$ and stomach $(\boldsymbol{L})$ in $\mathrm{Fz}_{3} 3^{-/-}$ embryos showed markedly diminished sympathetic innervation and branching compared with wild-type organs (kidneys, $I$; and stomach, $\boldsymbol{K})$. Higher-magnification images of the stomach $(\boldsymbol{M}, \boldsymbol{N})$ show poor arborization by sympathetic fibers in the stomach body wall in $\mathrm{Fz}^{-1-}$ embryos. Sympathetic projections along the mesenteric arteries are intact in $\mathrm{Fz}_{3}{ }^{-/-}$embryos ( $\mathbf{0}, \boldsymbol{P}$, arrows) while finer collaterals within the proximal part of the small intestine are absent in mutant embryos $(\boldsymbol{R})$ compared with wild-type (Q). Scale bars: $\mathbf{G}-\boldsymbol{R}, 500 \mu \mathrm{m} . n=7 \mathrm{E} 16.5$ embryos for each genotype were analyzed for these experiments.

greatly reduced sympathetic innervation of the kidneys, which receive innervation from paravertebral ganglia in rodents (compare wild-type in Fig. 5I with mutant in Fig. 5J). Fz $3^{-/-}$sympathetic axons were observed to extend along the renal arteries (Fig. $5 J$, arrowheads) but these extensions were very sparse and failed to arborize within the kidney parenchyma. The stomach and gastrointestinal tract, normally innervated by sympathetic fibers originating from the prevertebral celiac and mesenteric ganglia, also showed marked reductions in sympathetic innervation in $\mathrm{Fz}^{-1-}$ mice (stomach, Fig. $5 \mathrm{~L}, \mathrm{~N}$; intestine, Fig. $5 \mathrm{P}, \mathrm{R}$ ), compared with wild-type stomach (Fig. $5 K, M$ ) and intestine (Fig. 5O,Q). Sympathetic axons entered the stomach in $\mathrm{Fz}^{-1-} \mathrm{em}-$ bryos (Fig. $5 L$, arrowheads), but a closer examination revealed very little arborization in the stomach wall (Fig. $5 \mathrm{~N}$ ). For the
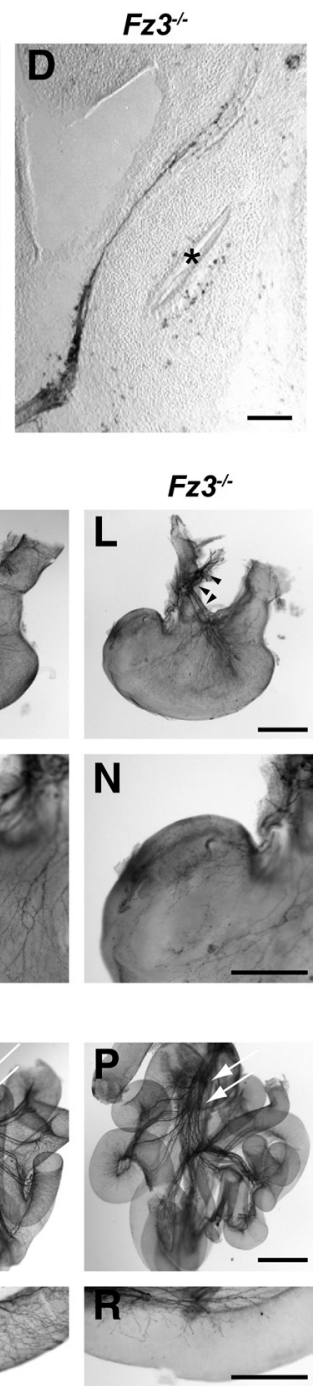

gastrointestinal tract, $\mathrm{Fz}^{-/-}$sympathetic axons coursed along the mesenteric vasculature as in wild-type embryos (Fig. 5P, arrows), but failed to enter and innervate the proximal small intestine (Fig. $5 R$ ). The attenuated sympathetic innervation of target tissues in E16.5 $\mathrm{Fz}^{-/-}$embryos cannot be attributed solely to reduced neuronal number. For example, the E16.5 stellate ganglia showed a $56 \%$ decrease in cell numbers in $\mathrm{Fz}^{-1-}$ embryos, yet, its target, the heart, showed a complete absence of sympathetic fibers. The more caudal thoracic and lumbar sympathetic chain ganglia showed only modest reductions in size at E16.5 (Fig. 1F,H), while pronounced decreases or absence of innervation were evident in their target organs by this stage. Additionally, in some cases, as in the stomach, kidneys and gastrointestinal tract, sympathetic axons were observed to project along the vasculature right up to the periphery of the target. Together, these results suggest an additional role for Fz3 in regulating sympathetic innervation of peripheral target tissues.

The target-derived neurotrophin, NGF, controls axonal extension and arborization when sympathetic axons have reached their final destinations. The deficits in sympathetic innervation of final peripheral targets observed in $\mathrm{Fz}^{-/-}$embryos are reminiscent of innervation defects observed in mice lacking NGF (Glebova and Ginty, 2004). To determine whether the diminished innervation in $\mathrm{Fz}^{-/-}$sympathetic targets reflected an inability of the axons to grow in response to NGF, we assessed NGF-dependent growth in SCG explants and dissociated cultures isolated from E18.5 wild-type and $\mathrm{Fz}^{-/-}$embryos. SCG explants were cultured in collagen gel for $48 \mathrm{~h}$ in the presence of NGF $(25 \mathrm{ng} / \mathrm{ml})$. Although the ganglia size in $\mathrm{Fz}^{-1-}$ was severely diminished by E18.5, neurites grew outward in a dense axonal halo, similar to wild-type SCGs (supplemental Fig. 4A, $B$, available at www. jneurosci.org as supplemental material). There were no significant differences in neurite outgrowth between wild-type and mutant explants (supplemental Fig. $4 C$, available at www.jneurosci.org as supplemental material) when quantified by measuring the area covered by the axons of each explant relative to the area occupied by the cell bodies. That the $\mathrm{Fz}^{-1-}$ SCG explants showed robust growth and no obvious signs of degeneration in the presence of NGF over the $48 \mathrm{~h}$ culture period, also suggests that $F z 3$ deletion does not affect NGF-dependent survival of sympathetic neurons. Examination of morphologies of isolated sympathetic neurons grown in low-density cultures and immunostained with $\beta$-IIItubulin (supplemental Fig. $4 D$, E, available at www.jneurosci.org as supplemental material) revealed no differences in neurite length (supplemental Fig. 4F, available at www.jneurosci.org as supplemental material) or branching (supplemental Fig. $4 G$, available at 
www.jneurosci.org as supplemental material) between wild-type and $\mathrm{Fz}^{-/-}$sympathetic neurons. Double immunofluorescence labeling to visualize microtubules and actin filaments did not show any obvious differences in morphology or cytoskeletal architecture in the growth cones of sympathetic neurons isolated from $\mathrm{Fz}^{-/-}$ and wild-type embryos (supplemental Fig. $4 H$, I, available at www. jneurosci.org as supplemental material). Together, these results suggest that sympathetic innervation deficits seen in $\mathrm{Fz}^{-/-}$embryos do not arise from an intrinsic inability to grow and branch in response to NGF, or deficiencies in growth cone morphologies.

During CNS development, Fz3 has been considered to predominantly employ the PCP signaling pathway to mediate axonal growth and targeting (Tissir et al., 2005; Wang and Nathans, 2007; Zhou et al., 2008; Fenstermaker et al., 2010). Additionally, double mutant mice lacking $F z 3$ and another Frizzled receptor, Frizzled6 show deficits in several PCP-dependent processes including neural tube and eyelid closure, and precise orientation of hair bundles on auditory/vestibular sensory cells (Wang et al., 2006b). Thus, we analyzed sympathetic nervous system development in the looptail mouse, which carries a loss-of-function mutation for a core PCP protein, Van Gogh-like 2 (Vangl2) (Kibar et al., 2001). In contrast to the $F z 3^{-/-}$embryos, we found no differences in SCG cell number between Vangl2 ${ }^{\mathrm{lp} / \mathrm{lp}}$ mutants and wildtype embryos at E16.5 (supplemental Fig. 5A, available at www. jneurosci.org as supplemental material). Whole-mount $\mathrm{TH}$ immunostaining also showed normal innervation of target tissues by sympathetic fibers in Vangl2 ${ }^{\mathrm{lp} / \mathrm{l} p}$ mice (supplemental Fig. $5 B-G)$. Together, these results indicate that Fz3-mediated regulation of sympathetic nervous system development occurs via a mechanism independent of Vangl2.

\section{Conditional ablation of $\boldsymbol{\beta}$-catenin in sympathetic ganglia results in enhanced cell cycle exit and reduced neurogenesis, but does not affect target innervation}

To determine the downstream signaling effectors that might mediate the effects of Fz3 in sympathetic ganglia, we then focused our attention on $\beta$-catenin, a critical component of the canonical Wnt signaling pathway and cadherin-dependent cell-cell adhesion. Loss-of-function and gain-of-function analyses in mice have established a fundamental role for $\beta$-catenin in proliferation and expansion of neuronal progenitors in the cortex, dorsal neural crest precursors and ventral midbrain dopaminergic neurons (Chenn and Walsh, 2002; Megason and McMahon, 2002; Woodhead et al., 2006; Tang et al., 2009, 2010). In perhaps the most noted example, expression of constitutively activated $\beta$-catenin in mice results in enlarged brains due to the propensity of cortical precursors to reenter the cell cycle and undergo symmetrical divisions (Chenn and Walsh, 2002). To study the role of $\beta$-catenin in sympathetic ganglia, we crossed transgenic $\mathrm{TH}$-Cre mice (Gong et al., 2007) with mice harboring a LoxP-based conditional $\beta$-catenin allele $\left(\beta\right.$-catenin $\left.{ }^{\text {flox/flox }}\right)$ (Brault et al., 2001), to ablate $\beta$-catenin specifically in cells of the sympathetic lineage. Analyses of the SCGs in TH-Cre; $\beta$-catenin flox/flox mice revealed a significant reduction in ganglia size (Fig. $6 A, B$ ) and cell number (Fig. 6C) by E16.5, compared with littermate controls that either lacked the TH-Cre transgene or carried a wild-type $\beta$-catenin allele. At E16.5, there were $9145 \pm 1977$ cells in TH-Cre; $\beta$-catenin flox/flox SCG, compared with $15,381 \pm 1277$ cells in wild-type ganglia. These results indicate a cellautonomous requirement for $\beta$-catenin in $\mathrm{TH}$-expressing sympathetic precursors for early SCG development. The significant reductions in SCG cell number in E16.5 embryos deficient for $\mathrm{Fz} 3$ and $\beta$-catenin suggested that Fz3 might be acting in part, via $\beta$-catenin, to promote neurogenesis. To further test this hypothesis, we monitored cell cycle progression in TH-Cre; $\beta$-catenin flox/flox embryos by labeling with EdU for $24 \mathrm{~h}$ and coimmunostaining with Ki67, thus analyzing how many progenitors have exited the cell cycle. Indeed, similar to the phenotype seen in E13.5 $\mathrm{Fz}^{-/-}$embryos, more progenitors exited the cell cycle during the $24 \mathrm{~h}$ time window in the TH-Cre; $\beta$-catenin flox/flox embryos, compared with wild-type control mice (Fig. 6D). At E13.5, 41\% of neuroblasts in THCre; $\beta$-catenin flox/flox SCG had exited the cell cycle compared with $29 \%$ of wild-type progenitors. Together, these results suggest that, like Fz3, $\beta$-catenin signaling in sympathetic ganglia positively regulates neurogenesis by maintaining sympathetic neuroblasts within the cell cycle.

To further investigate whether the loss of $\beta$-catenin recapitulates all the sympathetic deficits observed in $\mathrm{Fz}^{-/-}$embryos, we performed whole-mount $\mathrm{TH}$ immunostaining to assess sympathetic innervation of peripheral targets in TH-Cre; $\beta$-catenin flox/flox embryos. Remarkably, although the SCG cell number was significantly depleted in TH-Cre; $\beta$-catenin ${ }^{\text {flox/flox }}$ embryos, the pattern and extent of sympathetic innervation of target tissues in mutant embryos was largely indistinguishable from that in wild-type mice. Unlike $\mathrm{Fz}^{-/-}$ embryos, sympathetic fibers were observed to ramify in the parenchyma of the kidneys (Fig. $6 \mathrm{~F}$ ) and stomach (Fig. $6 \mathrm{H}, \mathrm{J}$ ) and within the proximal part of the small intestine (Fig. $6 \mathrm{~L}, \mathrm{~N}$ ) in E16.5 TH$\mathrm{Cre} ; \beta$-catenin ${ }^{\text {flox/flox }}$ mice, as in wild-type embryos (kidney, Fig. $6 \mathrm{E}$; stomach, Fig. $6 G$, I; and intestine, Fig. $6 K, M)$. Thus, although neuronal number is reduced with removal of $\beta$-catenin in sympathetic ganglia, axons of remaining neurons can reach their destinations and arborize to fully innervate target tissues. Together, these results suggest that the neurogenesis effect of Fz3 might be transduced via $\beta$-catenin signaling within sympathetic ganglia, while $\beta$-catenin is dispensable for mediating the Fz3-dependent innervation of sympathetic targets.

\section{Discussion}

Sympathetic neuroblasts, often referred to as "young neurons" are the immediate precursors of postmitotic sympathetic neurons, and they undergo multiple rounds of cell division to expand the precursor pool and increase sympathetic ganglia size before exiting the cell cycle. However, the molecular events that regulate expansion of sympathetic neuroblasts remain unknown. Using mice lacking $F z 3$, we now identify Fz3-mediated signaling as being essential for maintaining the proliferative capacity and survival of sympathetic neuroblasts. Fz3 is expressed in SCG at a stage when it is comprised primarily of proliferating sympathetic neuroblasts. In $\mathrm{Fz}^{-/-}$mice, sympathetic neuroblasts exit the cell cycle precociously and undergo apoptosis, leading to a depletion of progenitor cells and pronounced reductions in sympathetic ganglia size, as development proceeds. Moreover, conditional inactivation of $\beta$-catenin, a cytoplasmic Wnt effector, in cells of the sympathetic lineage resulted in neurogenesis deficits similar to that observed in $\mathrm{Fz}^{-/-}$mice. Together, these findings provide evidence in support of a Fz3/ $\beta$-catenin signaling pathway acting within sympathetic neuroblasts to regulate proliferation. Our analyses also uncover a temporally and mechanistically distinct role for Fz3 in promoting innervation of peripheral targets by postmitotic neurons, a function that is independent of $\beta$-catenin.

We found no effects of $F z 3$ deletion on the development of early neural crest cells, migration of neural crest-derived sympathetic progenitors and their acquisition of noradrenergic characteristics. Consistent with the notion that absence of $F z 3$ does not cause a broad loss of neural crest derivatives, we found no signif- 

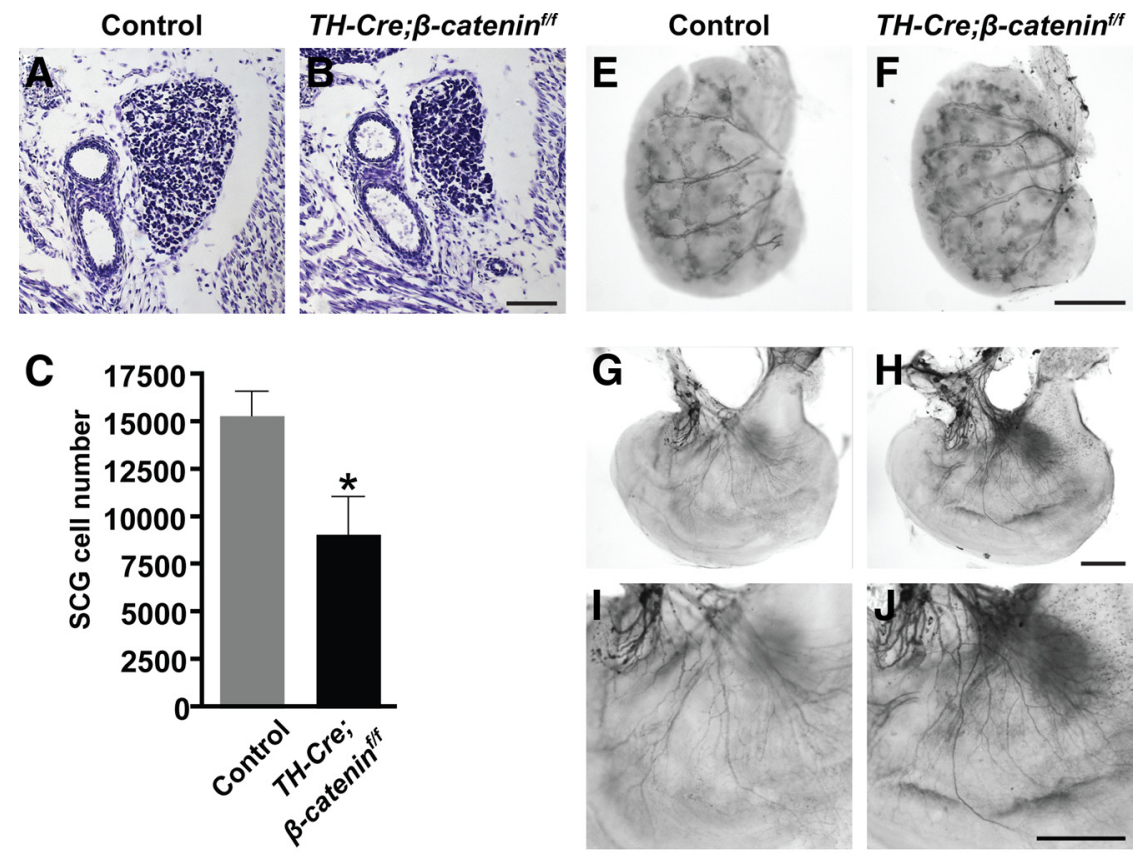

D

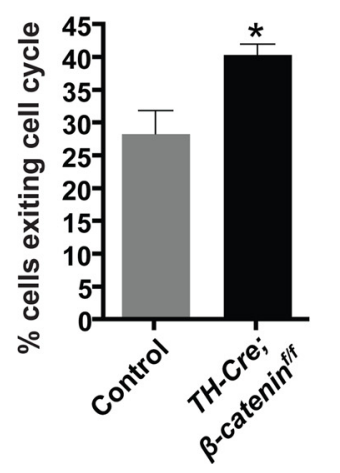

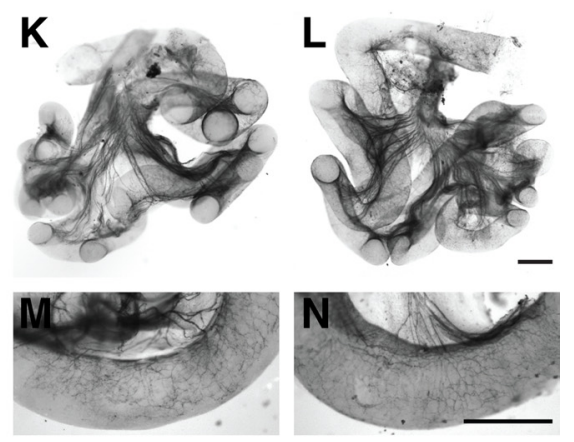
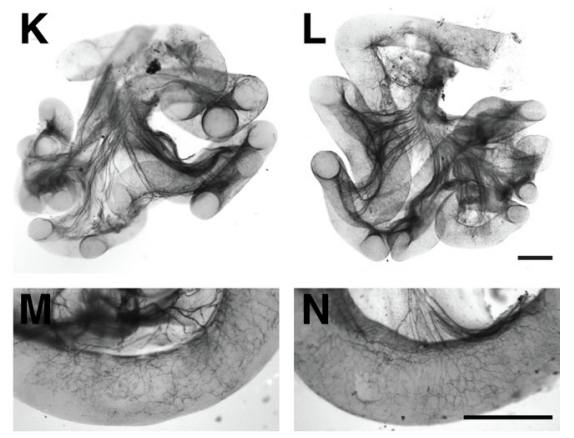

Figure 6. Conditional elimination of $\beta$-catenin in sympathetic ganglia influences cell cycle progression but not target innervation. $\boldsymbol{A}-\boldsymbol{C}$, Conditional ablation of $\beta$-catenin in the sympathetic lineage results in a reduction in SCG size $(\boldsymbol{B})$ and cell number $(\boldsymbol{C})$ in E16.5 TH-Cre; $\beta$-catenin flox/flox mice. Littermate $\beta$-catenin ${ }^{\text {flox/flox }}$ or TH-Cre mice were used as controls. Values are the mean \pm SEM ( $n=5$ embryos analyzed for control genotypes and $n=6$ for TH-Cre; $\beta$-catenin ${ }^{\text {flox/flox }}$ mice). Scale bar: $\boldsymbol{B}, 100 \mu \mathrm{m}$. ${ }^{*} p=$ 0.033. D, Analysis of cell cycle exit within a $24 \mathrm{~h}$ period (E12.5-E13.5) show that more cells exited the cell cycle in TH-Cre; $\beta$ catenin ${ }^{\text {flox/flox } S C G s}$ than in wild-type controls. Values are the mean \pm SEM ( $n=3$ embryos examined for each genotype). ${ }^{*} p=0.035$. $\boldsymbol{E}-\boldsymbol{N}$, Whole-mount TH immunostaining of target organs shows that sympathetic innervation in E16.5 TH-Cre; $\beta$-catenin ${ }^{\text {flox/flox }}$ embryos is comparable to that in control embryos: kidney $(\boldsymbol{E}, \boldsymbol{F})$, stomach $(\boldsymbol{G}-\boldsymbol{J})$, and intestine $(\boldsymbol{K}-\boldsymbol{N})$. Scale bars: $\boldsymbol{E}-\boldsymbol{N}, 500 \mu \mathrm{m}$.

icant abnormalities in dorsal root ganglia (unpublished results), which are also neural crest derived. The observed phenotypes in $\mathrm{Fz}^{-1-}$ embryos differ from those reported in other mouse mutants with neurogenesis deficits in the sympathetic nervous system. Mice lacking the transcription factors, Mash1 (Morikawa et al., 2009), Hand2 (Hendershot et al., 2008), Phox2b (Pattyn et al., 1999), Gata3 (Tsarovina et al., 2004) and Insm1 (Wildner et al., 2008), or defective in BMP signaling (Morikawa et al., 2009) show marked reductions in expression of noradrenergic markers and deficits in proliferation of early neural crest-derived sympathetic progenitors. Rather, our results identify Fz3 as being essential for maintaining immature neuroblasts already committed to a sympathetic neuronal fate in a dividing state. Interestingly, mice deficient for the transcription factor Sox 11 have been recently shown to exhibit reduced proliferation of TH-expressing sympathetic neuroblasts, similar to that seen in $\mathrm{Fz}^{-1-}$ embryos (Potzner et al., 2010). Several Sox transcription factors including

Sox2 (Van Raay et al., 2005), Sox9 (Blache et al., 2004) and Sox17 (Ye et al., 2009) are downstream mediators of Frizzled signaling and it remains to be determined whether Fz3 and Sox11 are involved in the same pathway that regulates sympathetic neuroblast proliferation.

The similar alterations in cell cycle exit and SCG size in $\mathrm{Fz}^{-/-}$mice, and mice with conditional deletion of $\beta$-catenin in the sympathetic lineage suggests that the proliferative effects of $\mathrm{Fz} 3$ are likely to be transduced by $\beta$-catenin. Previously, deleting $\beta$-catenin in Wnt1-expressing premigratory neural crest cells resulted in reduced sensory ganglia due to a role for $\beta$-catenin in specification of cells in the sensory neuron lineage, but sympathetic ganglia were reported to be normal (Hari et al., 2002). However, in our analyses, removal of $\beta$-catenin in neural crestderived cells already committed to a sympathetic lineage using $\mathrm{TH}$-Cre results in normal formation and aggregation of primordial sympathetic ganglia, but pronounced decrease in ganglia size later on due to reduced proliferation of sympathetic neuroblasts. Thus, the timing of $\beta$-catenin removal reveals distinct requirements for $\beta$-catenin during PNS development. $\beta$-Catenin could exert its effects by direct or indirect regulation of core components of the cell cycle machinery (Shtutman et al., 1999; Tetsu and McCormick, 1999; Megason and McMahon, 2002; ten Berge et al., 2008). $\beta$-Catenin might also influence proliferation of neuroepithelial progenitors through its function as an adhesion protein and regulation of adherens junction integrity and epithelial architecture in the developing cortex (Woodhead et al., 2006; Stocker and Chenn, 2009) and ventral midbrain (Tang et al., 2009). However, in the developing SCG, it remains unclear whether and how cell adhesion defects could underlie the reduced proliferation that we observed in $\beta$-catenin mutant mice.

The loss of Fz 3 and presumably $\beta$-catenin in sympathetic ganglia not only causes defects in proliferation, but also affects cell survival. Enhanced apoptosis is seen in early E13.5-E16.5 $\mathrm{Fz}^{-/-}$ SCG with significant reductions in ganglia size by E16.5 in both $\mathrm{Fz}^{-/-}$and $\beta$-catenin-mutant embryos. Several lines of evidence suggest that $\mathrm{Fz} 3$ depletion results in the apoptosis of an intermediate sympathetic population that has inappropriately exited the cell cycle, rather than the loss of actively dividing sympathetic precursors or mature postmitotic neurons depending on trophic support from final target tissues. First, we did not detect significant differences in apoptosis of proliferating sympathetic neuroblasts between wild-type and $\mathrm{Fz}^{-1-}$ embryos. Second, peak levels of apoptosis in the $F z 3^{-/-}$SCGs are observed at E16.5, just before the period of active sympathetic innervation of final targets. Concomitantly, reduction in cell numbers in the $\mathrm{Fz}^{-{ }^{--}}$ 
SCGs is complete by E16.5, and there is no further increase in apoptosis and depletion of cell numbers during the period of target-dependent trophic support of postmitotic sympathetic neurons at P0.5. In contrast, in mice lacking target-derived NGF signaling, excessive cell death in the SCG is first evident at E17.5 and is exacerbated postnatally, with near complete loss of mature sympathetic neurons a week after birth (Fagan et al., 1996; Glebova and Ginty, 2004). Last, the enhanced apoptosis observed in $\mathrm{Fz}^{-1-}$ SCG uses a Bax-independent pathway. The finding that SCG cell death in $\mathrm{Fz}^{-/-}$mice is not prevented by Bax removal contrasts sharply with the protection afforded by Bax elimination in postmitotic sympathetic neurons deprived of NGF (Middleton and Davies, 2001; Glebova and Ginty, 2004). Together, these findings suggest that the precise timing of production of postmitotic neurons is critical during development. Thus, sympathetic neuroblasts that improperly exit the cell cycle in the absence of $F z 3$ or $\beta$-catenin may not be exposed in a timely manner to regulatory signals necessary for proper transition to mature postmitotic neurons, and subsequently undergo cell death.

Previous analyses of $\mathrm{Fz}^{-/-}$mice showed dramatic losses in major axon tracts in the CNS but no phenotypes were observed in the PNS (Wang et al., 2002), presumably because the analyses were performed at early embryonic stages (E12.5) before the formation of sympathetic chain ganglia. We observed a complete absence or marked reduction of sympathetic fibers in many peripheral targets by E16.5 in $\mathrm{Fz}^{-/-}$embryos. Given the demonstrated role of $\mathrm{Fz} 3$ in axon guidance in the CNS (Lyuksyutova et al., 2003; Wang et al., 2006a), it is possible that failure of $\mathrm{Fz}^{-/-}$ sympathetic axons to enter final target areas reflects an axonal guidance function for Fz3. Axonal bundles emanating from the $\mathrm{Fz}^{-1-}$ sympathetic ganglia were defasciculated and more disorganized, suggesting that deficits in target innervation could stem, in part, from early navigational errors as soon as axons extend from the ganglia toward the periphery. However, at least for some targets such as the stomach and intestinal tract, $\mathrm{Fz}^{-1-}$ sympathetic axons were capable of approaching their final target fields, but failed to enter and fully innervate the entire target fields. Available evidence supports a role for PCP signaling in Fz3mediated axonal targeting in the CNS (Bovolenta et al., 2006; Wang and Nathans, 2007; Fenstermaker et al., 2010). Like PCPdependent processes, axon navigation is a directional cellular behavior that depends on cytoskeletal dynamics. Axonal targeting phenotypes observed in $\mathrm{Fz}^{-/-} \mathrm{CNS}$ are similar to those in mice lacking another well established PCP gene, Celsr3, encoding for a seven-pass transmembrane cadherin (Tissir et al., 2005; Zhou et al., 2008). We found normal sympathetic innervation of targets in Vangl2 ${ }^{\mathrm{lp} / \mathrm{l}}$ mutant mice, however, it is feasible that Vangl2 might function redundantly with other PCP components such as Celsr3 or Vangl1 in Fz3-dependent targeting of sympathetic fibers. Vangl1 is closely related to Vangl2 (with the proteins sharing $70 \%$ similarity) and functions redundantly with Vangl2 to mediate several PCP processes (Torban et al., 2008; Song et al., 2010). Further studies will delineate the contributions of PCP signaling in promoting Fz3-mediated axon targeting in the sympathetic nervous system.

Our work underscores the diversity of functions of a single Frizzled receptor, Fz3, in the developing nervous system. Fz3 function and mechanism of action is strongly context-dependent. In addition to its previously described roles in PCP-dependent processes, axonal outgrowth and guidance in the CNS, we uncover a critical role for Fz3 in sympathetic neurogenesis and target innervation in the PNS in this study.

\section{References}

Blache P, van de Wetering M, Duluc I, Domon C, Berta P, Freund JN, Clevers H, Jay P (2004) SOX9 is an intestine crypt transcription factor, is regulated by the Wnt pathway, and represses the CDX2 and MUC2 genes. J Cell Biol 166:37-47.

Bodmer D, Levine-Wilkinson S, Richmond A, Hirsh S, Kuruvilla R (2009) Wnt5a mediates nerve growth factor-dependent axonal branching and growth in developing sympathetic neurons. J Neurosci 29:7569-7581.

Bovolenta P, Rodriguez J, Esteve P (2006) Frizzled/RYK mediated signalling in axon guidance. Development 133:4399-4408.

Brault V, Moore R, Kutsch S, Ishibashi M, Rowitch DH, McMahon AP, Sommer L, Boussadia O, Kemler R (2001) Inactivation of the betacatenin gene by Wnt1-Cre-mediated deletion results in dramatic brain malformation and failure of craniofacial development. Development 128:1253-1264

Britsch S, Li L, Kirchhoff S, Theuring F, Brinkmann V, Birchmeier C, Riethmacher D (1998) The ErbB2 and ErbB3 receptors and their ligand, neuregulin-1, are essential for development of the sympathetic nervous system. Genes Dev 12:1825-1836.

Cappella P, Gasparri F, Pulici M, Moll J (2008) Cell proliferation method: click chemistry based on BrdU coupling for multiplex antibody staining. Curr Protoc Cytom Jul;Chapter 7:Unit7.34.

Chenn A, Walsh CA (2002) Regulation of cerebral cortical size by control of cell cycle exit in neural precursors. Science 297:365-369.

Ciani L, Salinas PC (2005) WNTs in the vertebrate nervous system: from patterning to neuronal connectivity. Nat Rev Neurosci 6:351-362.

Deckwerth TL, Elliott JL, Knudson CM, Johnson EM Jr, Snider WD, Korsmeyer SJ (1996) BAX is required for neuronal death after trophic factor deprivation and during development. Neuron 17:401-411.

DiCicco-Bloom E, Black IB (1988) Insulin growth factors regulate the mitotic cycle in cultured rat sympathetic neuroblasts. Proc Natl Acad Sci U S A 85:4066-4070.

DiCicco-Bloom E, Townes-Anderson E, Black IB (1990) Neuroblast mitosis in dissociated culture: regulation and relationship to differentiation. J Cell Biol 110:2073-2086.

DiCicco-Bloom E, Deutsch PJ, Maltzman J, Zhang J, Pintar JE, Zheng J, Friedman WF, Zhou X, Zaremba T (2000) Autocrine expression and ontogenetic functions of the PACAP ligand/receptor system during sympathetic development. Dev Biol 219:197-213.

Enomoto H, Crawford PA, Gorodinsky A, Heuckeroth RO, Johnson EM Jr, and Milbrandt J (2001) RET signaling is essential for migration, axonal growth and axon guidance of developing sympathetic neurons. Development 128:3963-3974.

Fagan AM, Zhang H, Landis S, Smeyne RJ, Silos-Santiago I, Barbacid M (1996) TrkA, but not TrkC, receptors are essential for survival of sympathetic neurons in vivo. J Neurosci 16:6208-6218.

Fenstermaker AG, Prasad AA, Bechara A, Adolfs Y, Tissir F, Goffinet A, Zou Y, Pasterkamp RJ (2010) Wnt/Planar cell polarity signaling controls the anterior-posterior organization of monoaminergic axons in the brainstem. J Neurosci 30:16053-16064.

Francis N, Farinas I, Brennan C, Rivas-Plata K, Backus C, Reichardt L, Landis S (1999) NT-3, like NGF, is required for survival of sympathetic neurons, but not their precursors. Dev Biol 210:411-427.

Glebova NO, Ginty DD (2004) Heterogeneous requirement of NGF for sympathetic target innervation in vivo. J Neurosci 24:743-751.

Glebova NO, Ginty DD (2005) Growth and survival signals controlling sympathetic nervous system development. Annu Rev Neurosci 28:191-222.

Gong S, Doughty M, Harbaugh CR, Cummins A, Hatten ME, Heintz N, Gerfen CR (2007) Targeting Cre recombinase to specific neuron populations with bacterial artificial chromosome constructs. J Neurosci 27:9817-9823.

Goridis C, Rohrer H (2002) Specification of catecholaminergic and serotonergic neurons. Nat Rev Neurosci 3:531-541.

Hari L, Brault V, Kléber M, Lee HY, Ille F, Leimeroth R, Paratore C, Suter U, Kemler R, Sommer L (2002) Lineage-specific requirements of betacatenin in neural crest development. J Cell Biol 159:867-880.

Hendershot TJ, Liu H, Clouthier DE, Shepherd IT, Coppola E, Studer M, Firulli AB, Pittman DL, Howard MJ (2008) Conditional deletion of Hand2 reveals critical functions in neurogenesis and cell type-specific gene expression for development of neural crest-derived noradrenergic sympathetic ganglion neurons. Dev Biol 319:179-191. 
Hendry IA (1977) Cell division in the developing sympathetic nervous system. J Neurocytol 6:299-309.

Howard MJ (2005) Mechanisms and perspectives on differentiation of autonomic neurons. Dev Biol 277:271-286.

Ikeya M, Lee SM, Johnson JE, McMahon AP, Takada S (1997) Wnt signalling required for expansion of neural crest and CNS progenitors. Nature 389:966-970.

Kawasaki T, Bekku Y, Suto F, Kitsukawa T, Taniguchi M, Nagatsu I, Nagatsu T, Itoh K, Yagi T, Fujisawa H (2002) Requirement of neuropilin 1 -mediated Sema3A signals in patterning of the sympathetic nervous system. Development 129:671-680.

Kibar Z, Vogan KJ, Groulx N, Justice MJ, Underhill DA, Gros P (2001) Ltap, a mammalian homolog of Drosophila Strabismus/Van Gogh, is altered in the mouse neural tube mutant Loop-tail. Nat Genet 28:251-255.

Lindsten T, Thompson CB (2006) Cell death in the absence of Bax and Bak. Cell Death Differ 13:1272-1276.

Lindsten T, Golden JA, Zong WX, Minarcik J, Harris MH, Thompson CB (2003) The proapoptotic activities of Bax and Bak limit the size of the neural stem cell pool. J Neurosci 23:11112-11119.

Lyuksyutova AI, Lu CC, Milanesio N, King LA, Guo N, Wang Y, Nathans J, Tessier-Lavigne M, Zou Y (2003) Anterior-posterior guidance of commissural axons by Wnt-frizzled signaling. Science 302:1984-1988.

Megason SG, McMahon AP (2002) A mitogen gradient of dorsal midline Wnts organizes growth in the CNS. Development 129:2087-2098.

Middleton G, Davies AM (2001) Populations of NGF-dependent neurones differ in their requirement for BAX to undergo apoptosis in the absence of NGF/TrkA signalling in vivo. Development 128:4715-4728.

Montcouquiol M, Rachel RA, Lanford PJ, Copeland NG, Jenkins NA, Kelley MW (2003) Identification of Vangl2 and Scrb1 as planar polarity genes in mammals. Nature 423:173-177.

Morikawa Y, Zehir A, Maska E, Deng C, Schneider MD, Mishina Y, Cserjesi P (2009) BMP signaling regulates sympathetic nervous system development through Smad4-dependent and -independent pathways. Development 136:3575-3584.

Patel TD, Jackman A, Rice FL, Kucera J, Snider WD (2000) Development of sensory neurons in the absence of NGF/TrkA signaling in vivo [see comments]. Neuron 25:345-357.

Pattyn A, Morin X, Cremer H, Goridis C, Brunet JF (1999) The homeobox gene Phox $2 \mathrm{~b}$ is essential for the development of autonomic neural crest derivatives. Nature 399:366-370.

Pincus DW, DiCicco-Bloom EM, Black IB (1990) Vasoactive intestinal peptide regulates mitosis, differentiation and survival of cultured sympathetic neuroblasts. Nature 343:564-567.

Potzner MR, Tsarovina K, Binder E, Penzo-Méndez A, Lefebvre V, Rohrer H, Wegner M, Sock E (2010) Sequential requirement of Sox4 and Sox11 during development of the sympathetic nervous system. Development 137:775-784.

Rohrer H, Thoenen H (1987) Relationship between differentiation and terminal mitosis: chick sensory and ciliary neurons differentiate after terminal mitosis of precursor cells, whereas sympathetic neurons continue to divide after differentiation. J Neurosci 7:3739-3748.

Rothman TP, Gershon MD, Holtzer H (1978) The relationship of cell division to the acquisition of adrenergic characteristics by developing sympathetic ganglion cell precursors. Dev Biol 65:322-341.

Rothman TP, Specht LA, Gershon MD, Joh TH, Teitelman G, Pickel VM, Reis DJ (1980) Catecholamine biosynthetic enzymes are expressed in replicating cells of the peripheral but not the central nervous system. Proc Natl Acad Sci U S A 77:6221-6225.

Rubin E (1985) Development of the rat superior cervical ganglion: ganglion cell maturation. J Neurosci 5:673-684.

Shtutman M, Zhurinsky J, Simcha I, Albanese C, D'Amico M, Pestell R, and Ben-Ze'ev A (1999) The cyclin D1 gene is a target of the beta-catenin/ LEF-1 pathway. Proc Natl Acad Sci U S A 96:5522-5527.
Song H, Hu J, Chen W, Elliott G, Andre P, Gao B, Yang Y (2010) Planar cell polarity breaks bilateral symmetry by controlling ciliary positioning. $\mathrm{Na}-$ ture 466:378-382.

Stocker AM, Chenn A (2009) Focal reduction of alphaE-catenin causes premature differentiation and reduction of beta-catenin signaling during cortical development. Dev Biol 328:66-77.

Tang M, Miyamoto Y, Huang EJ (2009) Multiple roles of beta-catenin in controlling the neurogenic niche for midbrain dopamine neurons. Development 136:2027-2038.

Tang M, Villaescusa JC, Luo SX, Guitarte C, Lei S, Miyamoto Y, Taketo MM, Arenas E, Huang EJ (2010) Interactions of Wnt/beta-catenin signaling and sonic hedgehog regulate the neurogenesis of ventral midbrain dopamine neurons. J Neurosci 30:9280-9291.

ten Berge D, Brugmann SA, Helms JA, Nusse R (2008) Wnt and FGF signals interact to coordinate growth with cell fate specification during limb development. Development 135:3247-3257.

Tetsu O, McCormick F (1999) Beta-catenin regulates expression of cyclin D1 in colon carcinoma cells. Nature 398:422-426.

Tissir F, Bar I, Jossin Y, De Backer O, Goffinet AM (2005) Protocadherin Celsr3 is crucial in axonal tract development. Nat Neurosci 8:451-457.

Torban E, Patenaude AM, Leclerc S, Rakowiecki S, Gauthier S, Andelfinger G, Epstein DJ, Gros P (2008) Genetic interaction between members of the Vangl family causes neural tube defects in mice. Proc Natl Acad Sci U S A 105:3449-3454

Tsarovina K, Pattyn A, Stubbusch J, Müller F, van der Wees J, Schneider C, Brunet JF, Rohrer H (2004) Essential role of Gata transcription factors in sympathetic neuron development. Development 131:4775-4786.

Van Raay TJ, Moore KB, Iordanova I, Steele M, Jamrich M, Harris WA, Vetter ML (2005) Frizzled 5 signaling governs the neural potential of progenitors in the developing Xenopus retina. Neuron 46:23-36.

Waimey KE, Huang PH, Chen M, Cheng HJ (2008) Plexin-A3 and plexin-A4 restrict the migration of sympathetic neurons but not their neural crest precursors. Dev Biol 315:448-458.

Wang Y, Nathans J (2007) Tissue/planar cell polarity in vertebrates: new insights and new questions. Development 134:647-658.

Wang Y, Thekdi N, Smallwood PM, Macke JP, Nathans J (2002) Frizzled-3 is required for the development of major fiber tracts in the rostral CNS. J Neurosci 22:8563-8573.

Wang Y, Zhang J, Mori S, Nathans J (2006a) Axonal growth and guidance defects in Frizzled3 knock-out mice: a comparison of diffusion tensor magnetic resonance imaging, neurofilament staining, and genetically directed cell labeling. J Neurosci 26:355-364.

Wang Y, Guo N, Nathans J (2006b) The role of Frizzled3 and Frizzled6 in neural tube closure and in the planar polarity of inner-ear sensory hair cells. J Neurosci 26:2147-2156.

White FA, Keller-Peck CR, Knudson CM, Korsmeyer SJ, Snider WD (1998) Widespread elimination of naturally occurring neuronal death in Baxdeficient mice. J Neurosci 18:1428-1439.

Wildner H, Gierl MS, Strehle M, Pla P, Birchmeier C (2008) Insml (IA-1) is a crucial component of the transcriptional network that controls differentiation of the sympatho-adrenal lineage. Development 135:473-481.

Woodhead GJ, Mutch CA, Olson EC, Chenn A (2006) Cell-autonomous beta-catenin signaling regulates cortical precursor proliferation. J Neurosci 26:12620-12630.

Ye X, Wang Y, Cahill H, Yu M, Badea TC, Smallwood PM, Peachey NS, Nathans J (2009) Norrin, frizzled-4, and Lrp5 signaling in endothelial cells controls a genetic program for retinal vascularization. Cell 139:285-298.

Zhou L, Bar I, Achouri Y, Campbell K, De Backer O, Hebert JM, Jones K, Kessaris N, de Rouvroit CL, O'Leary D, Richardson WD, Goffinet AM, Tissir F (2008) Early forebrain wiring: genetic dissection using conditional Celsr3 mutant mice. Science 320:946-949. 